\title{
Downregulation of miR-486-5p Enhances the Anti-Tumor Effect of 5-Fluorouracil on Pancreatic Cancer Cells [Corrigendum]
}

Wang W, Liu B, Sun S, et al. Onco Targets Ther. 2020;13:1649-1659.

The authors have advised due to an error at the time of figure assembly, duplicate images were used in Figure 1E on page 1652.


The correct Figure 1 is shown below. This error does not affect the results of the paper. The authors apologize for this error.

B
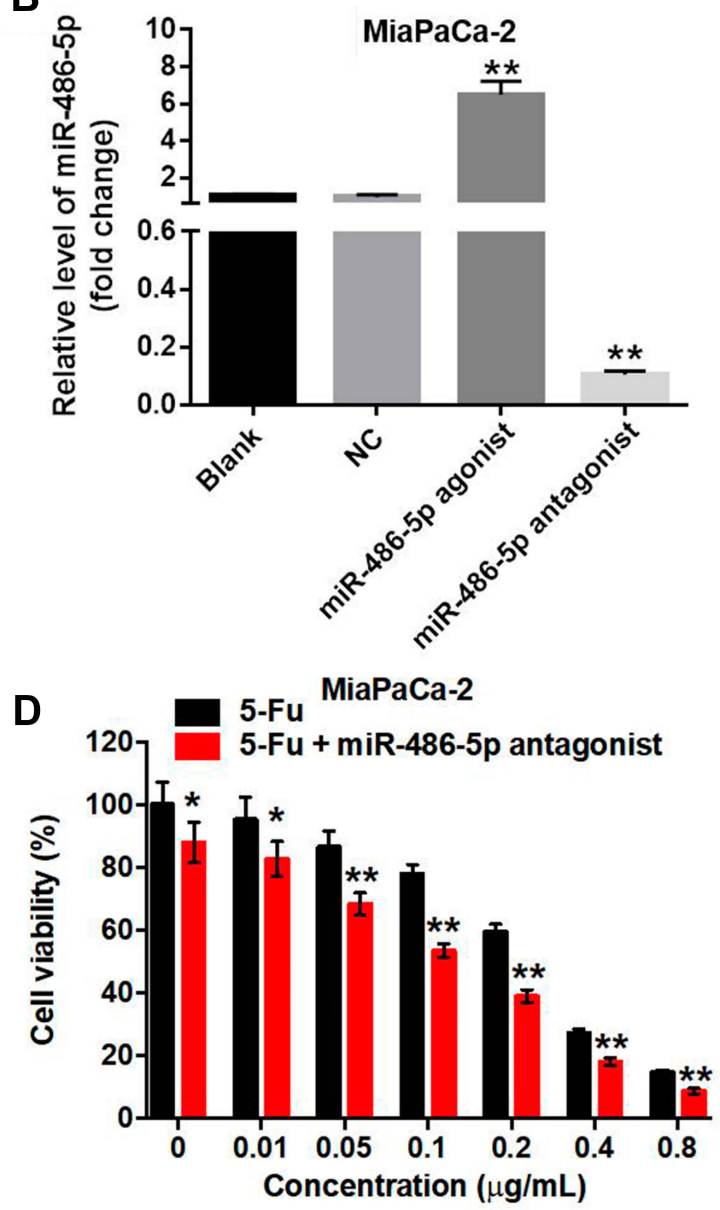

Figure I Continued. 

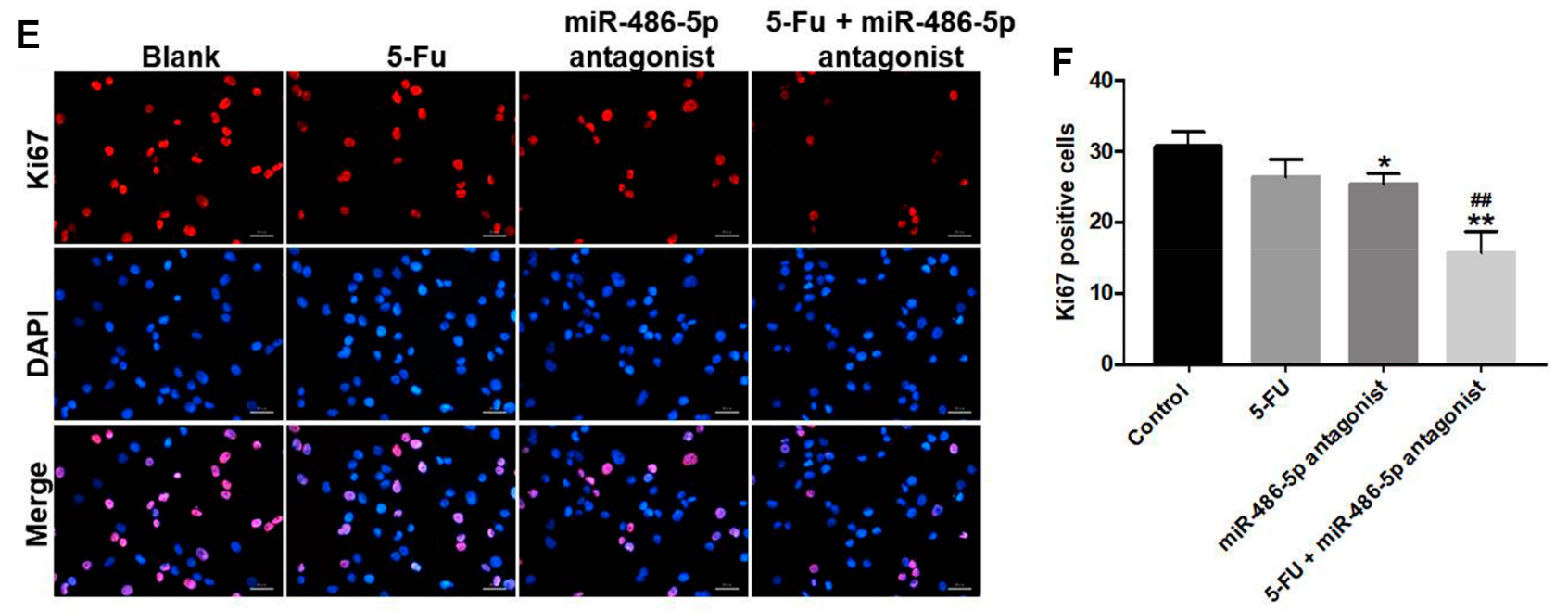

Figure I Downregulation ofmiR-486-5p enhanced the cytotoxic effect of 5-Fu in pancreatic cancer cells. (A) PANC-I and (B) MiaPaCa-2 cells were transfected with 10 nMmiR-486-5p agonist or 10 nMmiR-486-5p antagonist for 48 hrs. RT-qPCR was used to detect the level ofmiR-486-5p in PANC-I and MiaPaCa-2 cells. (C) PANC-I and (D) MiaPaCa-2 cells were transfected with $10 \mathrm{nM}$ miR-486-5p antagonist, and then exposed to 5-Fu for 48 hrs. Cell Counting Kit 8 assay was used to determine the cell viability.

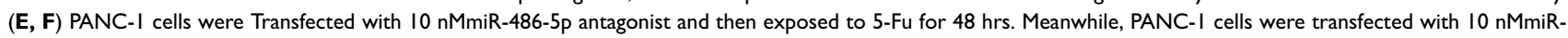
486-5p antagonist or exposed to 5 -Fu for 48 hrs, respectively. Relative fluorescence expressions were quantified by Ki67 and DAPI staining. $* \mathrm{P}<0.05$, **P<0.0I vs NC group; ${ }^{\# \prime} \mathrm{P}<0.01$ vs 5 -FU group.

\section{Publish your work in this journal}

OncoTargets and Therapy is an international, peer-reviewed, open access journal focusing on the pathological basis of all cancers, potential targets for therapy and treatment protocols employed to improve the management of cancer patients. The journal also focuses on the impact of management programs and new therapeutic agents and protocols on patient perspectives such as quality of life, adherence and satisfaction. The manuscript management system is completely online and includes a very quick and fair peer-review system, which is all easy to use. Visit http://www.dovepress.com/ testimonials.php to read real quotes from published authors. 